\title{
Effect of different organic inputs on growth and yield of Soybean (Glycine max. L) under mountainous conditions of Himachal Pradesh
}

\author{
Awasthi N. 凶, Upadhyay R. G., Singh A., Kumar R. and Sharma G. D.
}

Received: 01.09.2020

Revised: 14.10.2020

Accepted: 23.10.2020

\begin{abstract}
Current study was conducted to evaluate the influence of organic and zero budget natural farming on growth and yield of Soybean (Glycine max. L) under mountainous conditions of Himachal Pradesh. During the experimental period the variety of Soybean (Palam Soya) was sowed with eight treatments and three replications. The treatments consist of $T_{1}$ FYM-10t/ha+Rhizobium, $\mathrm{T}_{2}$-Vermicompost-7.5t/ha+Rhizobium, $\mathrm{T}_{3}$ - FYM- $5 \mathrm{t} / \mathrm{ha}+$ vermicompost -3.75 t/ha + Rhizobium-T -Natural farming (Ghanjivamrit+Jivamrit+Bijamrit), $T_{5}-$ FYM-10t/ha + vermiwash -3 spray, $T_{6}-$ Vermicompost- 10t/ha +vermiwash -3 spray, $T_{7^{-}}$Ghanjivamrit-125 kg/ha and $T_{8}-F Y M-5 t / h a+$ ghanjivamrit $-125 \mathrm{~kg} / \mathrm{ha}$ with $\mathrm{Randomized}$ Block Design (RBD). During the course of study significantly highest plant height (cm), number of leaves, number of branches at various growth stages, days taken to 50 percent flowering and maturity were influenced by vermicompost along with three sprays of vermiwash. The significantly highest biological yield $(2409.09 \mathrm{~kg} / \mathrm{ha})$, seed yield (825 $\mathrm{kg} / \mathrm{ha})$ and yield attributes of Soybean crop were recorded in the treatment $T_{6}-$ Vermicompost $@ 10 t / h a+3$ sprays of vermiwash during the experiment.
\end{abstract}

Key Words: Crop growth parameters, Organic farming, Soybean (Glycine max), Randomized block design (RBD), Farm yard manure (FYM)

\section{Introduction}

Soybean is one of the best leading crop commodities produced, traded and utilized globally. Barring some small portion, the bulk of it needs industrial processing and value addition. Besides its numerous uses, soybean is predominantly used as meal typically as source of high protein for animal feed and as edible oil. Soil organic matter plays indispensable role in some processes of the soil ecosystem including nutrient cycling, soil formation, carbon sequestration, retention of water and supply of energy to microorganisms (Lakaria et al., 2011). The organically growing foods have recently gained importance in developed and developing nations with the arising awareness about adverse effects of chemicals releases from agriculture on human health. The pronounced demand for organic growing food has increased worldwide which has led to increased interest in organic agriculture (Follet et al., 1981). At the time of cultivation of organically

\section{Author's Address}

College of Basic Sciences, CSKHPKV, Palampur-176062

Himachal Pradesh, India

E-mail.: awasthineha888@gmail.com growing crops, chemical usage is excluded at all stages so organic farming mainly provides the double benefit of quality of soil improvement and chemical free organic products (Gomiero et al., 2008). The organic matter of soil is the single most important constituent that affects the fertility of soil, formation of soil and other properties of soil in turn reflects in to better crop yield (Walker et al., 2004). The nitrogen and potassium content is higher in the vermicompost as compared to the vermiwash. However, the content of phosphorus was higher in the vermiwash as compared to the vermicompost. Vermiwash is a bio-fertilizer obtained from vermicomposting waste corn pulp blended with manure of cow dung. The $\mathrm{pH}$ and electrical conductivity is higher in the vermicompost as compared to the vermiwash. The vermiwash is richer in $\mathrm{Ca}$ and $\mathrm{Mg}$ as compared to the vermicompost. The vermiwash is rich in sodium content as compared to the vermicompost (Manyuchi et al., 2013). It increases the disease resistant capacity of crop (Yadav et al., 2005). It has been widely documented that soybean seed 


\section{Awasthi et al.}

constituents are not only genetically controlled, but affected by abiotic and biotic factors, such as the planting date, temperature, water conditions, soil conditions, agronomic practices, and diseases (Helms and Orff, 1998). In the present study experiment was conducted with an objective to see the effect of various treatments related to organic and zero budget natural agriculture application on health of soil and production of Soybean (Glycine $\max L$.) crop.

\section{Material and Methods}

A field experiment was conducted during JuneSeptember 2019 at the Research farm of Department of Organic Agriculture and Natural farming, CSKHPKV, Palampur (H.P.) to evaluate the influence of organic and zero budget natural agriculture on growth and yield of Soybean (Glycine max. L) under mountainous conditions of Himachal Pradesh. Soil of experimental field was silty, clayey and loamy in nature. It was also found high in organic carbon, slightly acidic with medium content of nitrogen $(\mathrm{N})$, phosphorous $(\mathrm{P})$ and high content of potassium $(\mathrm{K})$. The trial consists of eight treatments viz., $\mathrm{T}_{1}-\mathrm{FYM}$ 10t/ha+Rhizobium, $\mathrm{T}_{2}$ Vermicompost-

7.5t/ha+Rhizobium, $\mathrm{T}_{3}$-FYM-5t/ha+vermicompost3.75t/ha+Rhizobium, $\mathrm{T}_{4}$-Natural farming (Ghanjivamrit+Jivamrit+Bijamrit), $\quad \mathrm{T}_{5} \quad$-FYM$10 \mathrm{t} / \mathrm{ha}+$ vermiwash -3 spray, $\mathrm{T}_{6}$-Vermicompost10t/ha +vermiwash -3 spray, $\mathrm{T}_{7}-$ Ghanjivamrit$125 \mathrm{~kg} / \mathrm{ha}$ and $\mathrm{T}_{8}-\mathrm{FYM}-5 \mathrm{t} / \mathrm{ha}+$ ghanjivamrit $125 \mathrm{~kg} / \mathrm{ha}$. The experiment was laid out in RBD with three replications. For experimental purpose 24 plots of equal size $\left(3 \times 3 \mathrm{~m}^{2}\right)$ were prepared with the help of different composition of organic compost under eight treatments. The seeds of Soybean (Palam Soya variety) were sown and were used to record the morphological observations at various growth stages. The height of plant was measured in centimeters with the help of meter rod.The height of plant, branches per plant and leaves per plant were recorded at various growth stages while days to flowering and maturity in Soybean crop were recorded on the basis of visual observation. The plant $/ \mathrm{m}^{2}$, pods per plant, grain per pod, test weight, seed yield per plant, seed yield (kg /ha) and biological yield ( $\mathrm{kg} / \mathrm{ha})$ were recorded at the time of harvest. The harvest index of soybean (table 5.2) was calculated by method given by Donald and Hamblin (1976).

\section{Results and Discussion}

Morphological parameters like height of plant differed significantly due to application of different nutrient management treatments at all stages. Significantly highest plant height was recorded at $30,60,90$ and harvest (Table 1) with the application of $\mathrm{T}_{6}$-Vermicompost $10 \mathrm{t} / \mathrm{ha}+$ vermiwash- 3 Spray and lowest in $\mathrm{T}_{7}$ Ghanjivamrit $-125 \mathrm{~kg} / \mathrm{ha}$ (Table 1) due to maximum availability of nutrients in vermicompost and vermiwash as well as better uptake of nutrients from soil and translocation of photosynthates in different parts of plants .The application of $\mathrm{T}_{6}$-Vermicompost $-10 \mathrm{t} / \mathrm{ha}$ + vermiwash - 3 Spray recorded significantly higher number of branches per plant at all stages of development over the application of $\mathrm{T}_{7}$ Ghanjivamrit - $125 \mathrm{~kg} / \mathrm{ha}$ (Table 2). Organic manures found to improve the soil physical properties, which provide health and favourable soil conditions to enhance nutrient use efficiency, which leads to better vegetative growth of the plant. The significant improvement in number of leaves were recorded in $\mathrm{T}_{6}$-Vermicompost $10 \mathrm{t} / \mathrm{ha}+$ vermiwash- 3 Spray followed by $\mathrm{T}_{5}$ and $\mathrm{T}_{4}$. However, the treatment $\mathrm{T}_{7}$-Ghanjivamrit $125 \mathrm{~kg} / \mathrm{ha}$ recorded significantly lower number of leaves compared to all other treatments (Table 3). Organic manures enhance the nutrient balance and maintain the soil fertility of the particular area, which leads to more $\mathrm{N}$ uptake and photosynthetic activity. The days taken to flowering and maturity of soybean crop affected by the application of different organic manure and farming practices. Application of vermicompost $10 \mathrm{t} / \mathrm{ha}$ along with the three spray of vermiwash recorded significantly early flowering (48.38 days) followed by application of $\mathrm{T}_{5}$ (47.38 days). However the number of days taken to maturity by application of $\mathrm{T}_{7}$ (56.17) was much larger as compared to all other treatments (Table 4). Similar results were obtained by Aruna and Reddy (1999), and Soni and Vyas (1984). The yield and yield components were influenced by organic manures and natural farming (Table 5.1 and 5.2). Higher amount of pods per 
Table 1. Effect of various levels of organic manures and natural farming system on Plant height (cm)

\begin{tabular}{|c|c|c|c|c|}
\hline \multirow[t]{2}{*}{ Treatments } & \multicolumn{4}{|c|}{ Plant height (cm) Days after sowing (DAS) } \\
\hline & 30 & 60 & 90 & At Harvest \\
\hline$T_{1}-$ FYM-10 t/ha + rhizobium & 23.8 & 40.12 & 50.20 & 52.14 \\
\hline$T_{2^{-}}$Vermicompost - $7.5 \mathrm{t} / \mathrm{ha}+$ rhizobium & 23.9 & 41.23 & 53.21 & 54.25 \\
\hline$T_{3}$ - FYM- 5 t/ha + Vermicompost $-3.75 \mathrm{t} / \mathrm{ha}+$ rhizobium & 24.2 & 44.32 & 52.44 & 53.20 \\
\hline$T_{4}$ - Natural farming ( ghanjivamrit + jivamrit + bijamrit) & 23.8 & 43.05 & 51.24 & 53.21 \\
\hline$T_{5^{-}}$FYM -10 t/ha + vermiwash - 3 Spray & 24.3 & 44.50 & 53.71 & 55.81 \\
\hline$T_{6}$-Vermicompost -10 t/ha + vermiwash- 3 Spray & 25.4 & 46.80 & 57.23 & 56.90 \\
\hline$T_{7^{-}}$Ghanjivamrit - $125 \mathrm{~kg} / \mathrm{ha}$ & 23.1 & 39.22 & 47.21 & 48.72 \\
\hline$T_{8^{-}}$FYM -5t/ha+ ghanjivamrit- $125 \mathrm{~kg} / \mathrm{ha}$ & 23.3 & 43.4 & 49.58 & 50.84 \\
\hline SEm \pm & NS & 0.91 & 1.20 & 1.24 \\
\hline CD at $5 \%$ & NS & 2.94 & 3.70 & 3.64 \\
\hline
\end{tabular}

Table 2. Effect of various levels of organic manures and natural on number of branches per plant

\begin{tabular}{|l|l|l|l|l|}
\hline \multirow{2}{*}{ Treatments } & \multicolumn{4}{|l|}{ No. of Branches /plant Days after sowing (DAS) } \\
\cline { 2 - 5 } & $\mathbf{3 0}$ & $\mathbf{6 0}$ & $\mathbf{9 0}$ & At Harvest \\
\hline $\mathbf{T}_{\mathbf{1}}$ - FYM-10 t/ha + rhizobium & 5.4 & 5.9 & 5.7 & 5.0 \\
\hline $\mathbf{T}_{\mathbf{2}}$ - Vermicompost - 7.5 t/ha + rhizobium & 5.2 & 4.0 & 5.6 & 5.2 \\
\hline $\mathbf{T}_{\mathbf{3}}$ - FYM- 5 t/ha + Vermicompost -3.75 t/ha + rhizobium & 5.6 & 7.1 & 5.4 & 5.1 \\
\hline $\mathbf{T}_{\mathbf{4}}$ - Natural farming ( ghanjivamrit + jivamrit + bijamrit) & 5.2 & 5.0 & 5.6 & 6.9 \\
\hline $\mathbf{T}_{\mathbf{5}}$ - FYM -10 t/ha + vermiwash - 3 Spray & 5.0 & 8.0 & 7.6 & 7.2 \\
\hline $\mathbf{T}_{\mathbf{6}}$-Vermicompost -10 t/ha + vermiwash- 3 Spray & 5.8 & 10.0 & 9.6 & 12.0 \\
\hline $\mathbf{T}_{\mathbf{7}}$-Ghanjivamrit - 125 kg/ha & 5.0 & 4.0 & 4.9 & 4.5 \\
\hline $\mathbf{T}_{\mathbf{8}}$ - FYM -5t/ha+ ghanjivamrit- 125 kg/ha & 5.3 & 6.0 & 5.9 & 5.3 \\
\hline SEm \pm & $\mathrm{NS}$ & 0.09 & 0.11 & 0.085 \\
\hline CD at 5 \% & $\mathrm{NS}$ & 0.280 & 0.346 & 0.294 \\
\hline
\end{tabular}

Table 3. Effect of various levels of organic manures and natural farming on number of leaves per plant

\begin{tabular}{|l|l|l|l|l|}
\hline \multirow{2}{*}{ Treatments } & \multicolumn{4}{|c|}{ No. of Leaves/plant Days after sowing (DAS) } \\
\cline { 2 - 5 } & $\mathbf{3 0}$ & $\mathbf{6 0}$ & $\mathbf{9 0}$ & At Harvest \\
\hline $\mathbf{T}_{\mathbf{1}}$ - FYM-10 t/ha + rhizobium & 8.4 & 30.4 & 20.3 & 7.2 \\
\hline $\mathbf{T}_{\mathbf{2}}$ - Vermicompost - 7.5 t/ha + rhizobium & 9.1 & 32.1 & 20.2 & 8.6 \\
\hline $\mathbf{T}_{\mathbf{3}}$ - FYM- 5 t/ha + Vermicompost -3.75 t/ha + rhizobium & 9.6 & 30.8 & 19.4 & 9.1 \\
\hline $\mathbf{T}_{\mathbf{4}}$ - Natural farming ( ghanjivamrit+ jivamrit + bijamrit) & 10.8 & 34.1 & 18.9 & 8.7 \\
\hline $\mathbf{T}_{\mathbf{5}}$ - FYM -10 t/ha + vermiwash - 3 Spray & 11.4 & 34.8 & 20.8 & 10.6 \\
\hline $\mathbf{T}_{\mathbf{6}}$ - Vermicompost -10 t/ha + vermiwash- 3 Spray & 12.6 & 35.2 & 22.4 & 11.4 \\
\hline $\mathbf{T}_{\mathbf{7}}$ - Ghanjivamrit - 125 kg/ha & 7.6 & 27.0 & 16.4 & 6.3 \\
\hline $\mathbf{T}_{\mathbf{8}}$ - FYM -5t/ha+ ghanjivamrit- 125 kg/ha & 7.9 & 31.6 & 18.2 & 7.4 \\
\hline SEm \pm & 0.23 & 0.68 & 0.51 & 0.23 \\
\hline CD at 5 \% & 0.79 & 2.84 & 1.71 & 0.81 \\
\hline
\end{tabular}

plant (54.35) were recorded in the application of maturity due to lesser supply of photosynthates $\mathrm{T}_{6^{-}} \quad$ Vermicompost -10 t/ha + vermiwash- 3 Spray towards the pods because of drying and while lower amount of pods (33.21) were recorded senescence of leaves. Significantly the highest in the treatment $\mathrm{T}_{7^{-}}$Ghanjivamrit $-125 \mathrm{~kg} / \mathrm{ha}$. The biological yield was $(2409.09 \mathrm{~kg} / \mathrm{ha})$ recorded in the lowest number of pods might be a result of application of vermicompost $10 \mathrm{t} / \mathrm{ha}$ in treatment nutrients at the late stages of crop which in T6 However, the lowest biological yield was legumes, usually result in pod shedding before $(1625.00 \mathrm{~kg} / \mathrm{ha})$ recorded in treatment $\mathrm{T}_{7}$ - 
ghanjivamrit - $125 \mathrm{~kg} / \mathrm{ha}$. The application of Vermicompost $-10 \mathrm{t} / \mathrm{ha}+$ vermiwash- 3 spray recorded significantly highest number of grain per pod (12.0) over the application of $\mathrm{T}_{7}$ Ghanjivamrit - $125 \mathrm{~kg} / \mathrm{ha}$.

Significantly the highest seed yield per plant was $(41.25 \mathrm{~g})$ recorded in the $\mathrm{T}_{6}$ vermicompost $10 \mathrm{t} / \mathrm{ha}$ with three sprays of vermiwash. However the lowest seed yield per plant (26.75 g) was recorded in the treatment $\mathrm{T}_{7}$-ghanjivamrit $-125 \mathrm{~kg} / \mathrm{ha}$. The significantly highest test weight was (173.22 g) recorded in $\mathrm{T}_{6^{-}}$vermicompost $10 \mathrm{t} / \mathrm{ha}+$ vermiwash- 3 spray as compared to all other treatments. However, the lowest test weight was $(140.22 \mathrm{~g})$ recorded in the treatment $\mathrm{T}_{7}$ ghanjivamrit $-125 \mathrm{~kg} / \mathrm{ha}$

.Application of vermicompost along with the three spray of vermiwash recorded significantly higher seed yield per hectare in $\mathrm{T}_{6}(825.0 \mathrm{~kg} / \mathrm{ha})$. However, treatment $\mathrm{T}_{7}$-ghanjivamrit $-125 \mathrm{~kg} / \mathrm{ha}$ recorded lowest seed yield $(520.0 \mathrm{~kg} / \mathrm{ha})$ as comparison to all other treatments. The overall growth and development of crop is reflected in the development of yield contributing characters which affect the final yield of the crop as these parameters are positively correlated to seed yield. Yield is the synthesis and outcome of physiological biochemical process. Significantly highest harvest index was $(0.36 \%)$ recorded in $\mathrm{T}_{6^{-}}$vermicompost $10 \mathrm{t} / \mathrm{ha}$ with three spray of vermiwash .However, the lowest was $(0.29 \%)$ recorded in treatment $\mathrm{T}_{7}$ ghanjivamrit $-125 \mathrm{~kg} / \mathrm{ha}$. Similar results were also observed by several researchers (More et al., 2008; Pattanshetti et al., 2002; Rana and Badiyala, 2014).

Table 4. Effect of various levels of Organic manures and natural farming on days taken to $50 \%$ flowering and days taken to maturity

\begin{tabular}{|l|l|l|}
\hline Treatments & $\begin{array}{l}\text { Days taken to mat } \\
\text { urity }\end{array}$ & $\begin{array}{l}\text { Days taken to 50 per ce } \\
\text { ntflowering }\end{array}$ \\
\hline $\mathbf{T}_{\mathbf{1}}$ - FYM-10 t/ha + rhizobium & 152.52 & 54.22 \\
\hline $\mathbf{T}_{\mathbf{2}}$ - Vermicompost - 7.5 t/ha + rhizobium & 146.25 & 53.22 \\
\hline $\mathbf{T}_{\mathbf{3}}$ - FYM- 5 t/ha + vermicompost -3.75 t/ha + rhizobium & 148.25 & 53.25 \\
\hline $\mathbf{T}_{\mathbf{4}}$ - Natural farming (ghanjivamrit + jivamrit + bijamrit) & 143.85 & 54.21 \\
\hline $\mathbf{T}_{\mathbf{5}}$ - FYM -10 t/ha + vermiwash - 3 Spray & 139.82 & 49.38 \\
\hline $\mathbf{T}_{\mathbf{6}}$ - Vermicompost -10 t/ha + vermiwash- 3 Spray & 135.85 & 48.38 \\
\hline $\mathbf{T}_{\mathbf{7}}$ - Ghanjivamrit - 125 kg/ha & 155.25 & 56.17 \\
\hline $\mathbf{T}_{\mathbf{8}}$ FYM -5t/ha+ ghanjivamrit- 125 kg/ha & 155.55 & 53.22 \\
\hline SEm \pm & 0.43 & 0.32 \\
\hline CD at 5 \% & 1.52 & 0.98 \\
\hline
\end{tabular}

Table 5.1. Effect of various levels of organic manures and natural farming yield and yield components

\begin{tabular}{|l|l|l|l|l|}
\hline Treatments & $\begin{array}{l}\text { No. of pods } \\
\text { per plant }\end{array}$ & $\begin{array}{l}\text { No. of grain } \\
\text { per pod }\end{array}$ & $\begin{array}{l}\text { Test we } \\
\text { ight (g) }\end{array}$ & $\begin{array}{l}\text { Seed yield } \\
\text { per plant }\end{array}$ \\
\hline $\mathbf{T}_{\mathbf{1}}$ - FYM-10 t/ha + Rhizobium & 43.85 & 7.50 & 156.35 & 29.10 \\
\hline $\mathbf{T}_{\mathbf{2}}$ - Vermicompost - 7.5 t/ha + Rhizobium & 45.47 & 7.80 & 166.96 & 39.75 \\
\hline $\mathbf{T}_{\mathbf{3}}$ - FYM- 5 t/ha + Vermicompost -3.75 t/ha + Rhizobium & 48.45 & 9.00 & 167.25 & 39.75 \\
\hline $\mathbf{T}_{\mathbf{4}}$-Natural farming ( Ghanjivamrit + Jivamrit + Bijamrit & 41.66 & 7.90 & 163.96 & 26.80 \\
\hline $\mathbf{T}_{\mathbf{5}}$ - FYM -10 t/ha + Vermiwash - 3 Spray & 49.35 & 11.00 & 170.33 & 38.40 \\
\hline $\mathbf{T}_{\mathbf{6}}$-Vermicompost -10t/ha + Vermiwash- 3 Spray & 54.35 & 12.00 & 173.22 & 41.25 \\
\hline $\mathbf{T}_{\mathbf{7}}$ - Ghanjivamrit-125kg/ha & 33.21 & 6.8 & 140.20 & 26.75 \\
\hline $\mathbf{T}_{\mathbf{8}}$ - FYM-5t/ha+ Ghanjivamrit- 125 kg/ha & 45.75 & 8.20 & 149.35 & 34.45 \\
\hline SEm \pm & 0.78 & 0.31 & 0.80 & 0.61 \\
\hline CD at 5\% & 2.78 & 0.97 & 2.69 & 2.03 \\
\hline
\end{tabular}


Table 5.2 Effect of various levels of organic manures and natural farming yield on seed yield (kg/ha), Biological yield(kg/ha) and harvest index(\%)

\begin{tabular}{|c|c|c|c|}
\hline Treatments & $\begin{array}{l}\text { Seed yield } \\
(\mathrm{kg} / \mathrm{ha})\end{array}$ & $\begin{array}{l}\text { Biological } \\
\text { yield (kg/ ha) }\end{array}$ & $\begin{array}{l}\text { Harvest } \\
\text { Index (\%) }\end{array}$ \\
\hline$T_{1}-$ FYM-10 t/ha + rhizobium & 582.0 & 1877.42 & 0.31 \\
\hline$T_{2}$ - Vermicompost - $7.5 \mathrm{t} / \mathrm{ha}+$ rhizobium & 795.0 & 2194.0 & 0.33 \\
\hline$T_{3}$ - FYM- 5t/ha + vermicompost -3.75 t/ha + rhizobium & 795.0 & 2291.0 & 0.34 \\
\hline $\mathrm{T}_{4}$ - Natural farming (ghanjivamrit + jivamrit + bijamrit) & 535.0 & 1844.83 & 0.32 \\
\hline$T_{5}$ FYM -10 t/ha + vermiwash - 3 Spray & 768.0 & 2338.38 & 0.35 \\
\hline$T_{6}$ - Vermicompost -10t/ha + vermiwash- 3 Spray & 825.0 & 2409.09 & 0.36 \\
\hline $\mathrm{T}_{7^{-}}$Ghanjivamrit-125kg/ha & 520.0 & 1625.00 & 0.29 \\
\hline$T_{8}-$ FYM -5t/ha+ ghanjivamrit- $125 \mathrm{~kg} / \mathrm{ha}$ & 689.0 & 2153.13 & 0.32 \\
\hline SEm \pm & 1.43 & 1.48 & 0.03 \\
\hline CD at $5 \%$ & 4.59 & 5.21 & NS \\
\hline
\end{tabular}

\section{Conclusion}

Different growth parameters, yield attributes, seed yield, biological yield, test weight and harvest Index of soybean were improved significantly with

\section{References}

Aruna and Reddy, N. S. 1999. Response of soybean (Glycine $\max )$ to conjunctive use of organic and inorganic sources of nitrogen . Indian Journal of Agricultural Sciences, 69(5): 382-383.

Donald, C. M. and Hamblin, J. 1976. The biological yield and harvest index of cereals as agronomic and plant breeding criteria. Advances in Agronomy, 28(3): 361-405.

Follet, R., Donahue, R. and Murphy, L. 1981. Soil and soil amendments. Prentice hall Inc, New Jersey.

Gomiero, T., Paoletti, M. G. and Pimentel, D. 2008. Energy and environmental issues in organic and conventional agriculture. CRC Critical Reviews in Plant Sciences, 27: 239-254.

Helms, T. C. and Orff, J. H. 1998. Protein, oil, and yield of soybean lines selected for increased protein. Crop Science, 38:707-711.

Lakaria, B. L., Jha, P. and Biswas, A. K. 2011. Soil carbon dynamics under long term use of organic manures. In: Singh, A. B., Sammi, Reddy, K., Manna, M. C. and Subba, Rao, A. (Eds.), Recycling Organic Wastes for Soil Health and Productivity, Agrotech Publishing Academy, Udaipur, Rajasthan, India, 83-93.

Manyuchi, M. M., Phiri, A., Muredzi, P. and Chitambwe, T. 2013. Comparison of vermicompost and vermiwashbiofertilizers from vermicomposting waste corn pulp. In Proceedings of World Academy of Science , Engineering and Technology (WASET), 78: 346. the application of vermicompost@10t/ha along with 3 sprays of vermiwash as compared to other treatments under mountainous conditions of Himachal Pradesh.

More, S. R., Mendhe, S. N., Kolte H. S., Yenpediwar, M. D. and Choudhary, R. L. 2008. Growth and yield attributes of soybean as influenced by nutrient management. Journal of Soils and Crops, 18(1): 154-157.

Pattanshetti, V. A., Agasimani, C. A. and Babalad, H. B. 2002. Effect of manures and fertilizers on yield of maize and soybean under intercropping. Journal of Maharashtra Agricultural Universities, 27(2): 206-207.

Rana, R. and Badiyala, D. 2014. Effect of integrated nutrient management on seed yield, quality and nutrient uptake of soybean (Glycine max) under mid hill conditions of Himachal Pradesh. Indian Journal of Agronomy, 59(4): 641-645.

Soni, J. C. and Vyas, M. D. 1984. Effect of different, levels of phosphate on the growth, yield and quality of new promising varieties of soybean. M.Sc. (Ag.) Thesis, JNKVV, Jabalpur.

Walker, D. J., Clemente, R. and Bernal, M. P. 2004. Contrasting effects of manure and compost on soil $\mathrm{pH}$, heavy metal availability and growth of Chenopodium album L. in a soil contaminated by pyritic mine waste. Chemosphere, S7: 215-224.

Yadav, A. K., Kumar, K., Singh, S. and Sharma, M. 2005. Vermiwash: A liquid bio fertilizer. Uttar Pradesh Journal of Zoology, 25(1): 97-99. 